\title{
Metabolisable energy value of rapeseed meal and its fractions for chickens as affected by oil and fibre content
}

\author{
M. Chibowska, S. Smulikowska ${ }^{1}$ and B. Pastuszewska \\ The Kielanowski Institute of Animal Physiology and Nutrition, \\ Polish Academy of Sciences \\ 05-llo Jabtonna, Poland
}

(Received 10 October 1999; accepted 8 May 2000)

\begin{abstract}
Low glucosinolate rapeseed meal (RM) was separated on sicves of 150,270 and $450 \mu \mathrm{m}$ diameter into 3 fractions defined as flour, bran and hulls. The fractions and rape seed oil were mixed in different proportions in order to obtain 25 model rapeseed meals differing in crude fibre $8.8,10.3$, $11.8,13.2$ and $14.7 \%$ DM and in crude fat 4.3,6.3,8.2, 10.2 and 12.1\% DM (two-factorial design).

The digestibility of nutrients and apparent metabolisable energy $\left(\Lambda M E_{N}\right)$ of $R M$, fractionatcd material and model RMs was evaluated in two balance experiments conducted on 154 broiler chicken aged 4 weeks. After removal of bran and hulls, the protein content as well as $\mathrm{AME}_{\mathrm{N}}$ value of the remaining fraction increased by 16 and $10 \%$, respectively, in comparison with RM. Crude fibre content negatively and crude fat content positively affected $A M E_{N}$ value of model $R M s(P \leq 0.01)$ according to the equation: $\Lambda \mathrm{ME}_{\mathrm{N}}(\mathrm{MJ} / \mathrm{kg} \mathrm{DM})=10.78-0.30(\%$ crude fibre $)+0.20(\%$ crude fat $)$.
\end{abstract}

KEY WORDS: rapeseed meal, dehulling, metabolisable energy, chickens

\section{INTRODUCTION}

The use of low-glucosinolate rapeseed meal in diets for poultry is limited by its low energy value, which is largely attributed to the low content of oil and the high content of dictary fibre. Dietary fibre (insoluble and soluble) is present both in

\footnotetext{
' Corresponding author
} 
cotyledons and in seed coat (hulls), in the latter prevails insoluble fibre (Bjergegaard et al., 1991). Both types of fibres are not digested by poultry. Due to substantial differences in oil and fibre content the metabolisable encrgy value for poultry in Polish rapeseed meals may range from 6 to $10.5 \mathrm{MJ} / \mathrm{kg} \mathrm{DM}$ (Hanczakowski and Fraś, 1983; Alloui et al., 1994; Nutrient Requirement of Poultry, 1996; Smulikowska et al., 1998; Smulikowska, unpublished). It is possible to manipulate the content of fibre and fat in rapeseed meals; the fat content may be increased due to lower extraction rate or omitting the final extraction process (Smulikowska ct al., 1998), a viable means to reduce the hull (and fibre) content represent new technologies of dehulling (de Lange et al., 1998). The quantification of the fibre and fat cffects on the energy value of rapeseed meal may help to choose the most efficient strategy of upgrading this feedstuff for poultry.

The objective of this study was to determine the chemical composition and metabolisable energy for chickens of fractions obtained due to mechanical segregation of commercial low glucosinolate rapeseed meal (RM) and to elaborate the regression equations for predicting the metabolisable energy value of RM from its chemical composition.

\section{MATERIAL AND METHODS}

Commercial solvent extracted rapeseed meal produced from seeds of low glucosinolate brown-seeded variety Bolko (RM) was used. RM was separated in Quadrumat Senior Mill on sicves of 150,270 and $450 \mu \mathrm{m}$ diameter into 3 fractions: flour, bran and hull in proportions as $3: 2: 1$. Hulls were further defatted with petroleum ether.

Two balance experiments were performed on 3 weck old broiler chickens with the average body weight about $450 \mathrm{~g}$. The chickens were housed in individual cages equipped for the quantitative collection of excreta, in a controlled environment with $24 \mathrm{~h}$ light/day.

In both experiments test diets were composed of basal diet and tested materials combined in proportion of 60:40 on DM basis; the basal diet was composed of $(\%)$ : wheat 50 , soyabean oilmeal 20 , wheat flour 24 , casein 2 , mineral-vitamin premix 4 . Basal and test diets were cold pelleted, $100 \mathrm{~g}$ of feed per bird was offered daily in 3 portions. After 2 days the birds were kept fasting for $24 \mathrm{~h}$, and then were offered the same diet for the next 3 days. Feed consumption was measured, excreta were collected daily during the feeding period and consecutive $24 \mathrm{~h}$ of fast, frozen immediately and stored at $-18^{\circ} \mathrm{C}$.

In experiment 1 performed on 50 cockerels divided on 5 groups basal diet was fed alone or mixed (60:40) with: RM, flour, bran or defatted hulls. In experiment 2 performed on 99 cockerels divided into 26 groups basal diet was fed as such to 
group of 10 birds or was mixed (60:40) with model rapeseed meals (M-RMs) and fed to groups of 3 or 4 chickens. The M-RMs were prepared from flour, bran, defatted hulls and rape seed oil mixed in order to obtain 25 meals of crude fibre content of $8.8 ; 10.3 ; 11.8 ; 13.2$ and $14.7 \% \mathrm{DM}$ and crude fat content of $4.3 ; 6.3$; $8.2 ; 10.2 ; 12.1 \%$ DM (two-factorial design).

In RM and its fractions, model RMs, diets and freeze-dried excreta chemical composition was determined by standard methods (AOAC, 1990), gross energy by Parr adiabatic oxygen bomb calorimeter KL-10, neutral detergent fibre (NDF) and acid detergent fibre (ADF) content according to Van Soest and Wine (1967) on a Fibertec M (Tecator) apparatus. Condensed tannins were determined by modificd vanillin method according to Kuhla and Ebmeier (1981), glucosinolates by YoungsWetter method modified by Byczyńska (1971), uric acid in excreta according to Marquardt (1983).

Apparent metabolisable energy corrected to zero $\mathrm{N}$ balance $\left(\mathrm{AME}_{\mathrm{N}}\right)$ and apparent digestibility of crude protein, crude fat and fibre were calculated according to Campbell et al. (1983) and Pesti and Ware (1986).

The data of experiment 1 were subjected to one way analysis of variance, experiment 2 to two way analysis of variance and multiple regression analysis using Statgraphics ver. 7 software.

\section{RESULTS}

The glucosinolate content in RM and its fractions obtained due to mechanical segregation was very low and amounted to $0.3-0.9 \mu \mathrm{M} / \mathrm{g}$ fat-free DM. Fractions differed in their chemical composition, flour contained more protein and ash but less fat, fibre (crude fibre (CF), ADF, NDF) and tannins than RM, bran or hulls (Table 1). Total dictary fibre constituted about $41 \%$ of RM (in it about $30 \%$ was determined as $\mathrm{CF}, 57 \%$ as ADF, $90 \%$ as NDF), respective values for flour were 35 , 26.40 and $78 \%$, for hull fraction $54,35,73$ and $94 \%$ (Table 1). The amino acid composition of protein did not differ to the great extent, the protein in flour containcd about $10 \%$ more sulphur amino acids than in RM, the hull protein contained less of some non-cssential amino acids (glutamic acid, glycine, alanine) as well as some essential ones (arginine, histidine, leucine) than RM protcin (Table 2).

The results of the digestibility trial are presented in Table 3 . The retention of organic matter and digestibility of fat in the flour fraction was higher than in RM by about 2 percentage points, the apparent protein digestibility, NFE and NDF digestibility was higher by about 10,8 and 6 percentage points, respectively $(\mathrm{P} \leq 0.01)$. On the contrary, in the hull fraction apparent protein digestibility and fat digestibility was about 30 percentage points lower than in $\mathrm{RM}(\mathrm{P} \leq 0.01)$. It means that $100 \mathrm{~g}$ of flour contained about $34 \mathrm{~g}$ of digestible protein, but the same amount 
of hull only $8.3 \mathrm{~g}$. The amount of digestible fat in flour and hull was comparable ( 2.5 and $2.2 \mathrm{~g}$, respectively) due to higher fat content in hull fraction. Fibre content significantly $(\mathrm{P} \leq 0.01)$ affected retention of organic matter and digestibility of fat in RM and its fractions, the correlation coefficients with CF content were higher $(r=-0.90$ and -0.83$)$ than with ADF $(r=-0.85$ and -0.78$)$ and NDF content $(\mathrm{r}=-0.80$ and -0.73 , respectively).

Gross energy of RM and its fractions was comparable (20 to $20.3 \mathrm{MJ} / \mathrm{kg} \mathrm{DM}$ ). however metabolizability of energy was in flour by $11 \%$ higher and in hull fraction by $23 \%$ lower than in RM. As a result metabolisable energy value of flour was

TABLE 1

Chemical composition of RM and its fractions, in DM \%

\begin{tabular}{lccccc}
\hline Component & RM & Flour & Bran & Huils & 'Huils \\
\hline Crude protein & 36.2 & 42.0 & 31.0 & 23.9 & 24.2 \\
Crude fat & 4.2 & 3.3 & 4.2 & 6.7 & 5.0 \\
Sugar & 11.2 & 11.8 & 11.3 & 9.4 & 9.9 \\
Ash & 7.7 & 8.2 & 7.0 & 6.4 & 6.5 \\
Crude fibre & 12.0 & 8.9 & 14.9 & 18.9 & 19.2 \\
ADF & 23.1 & 13.7 & 32.2 & 39.1 & 40.0 \\
NDF & 36.5 & 27.1 & 47.4 & 50.3 & 51.9 \\
Total dietary fibre & 40.7 & 34.7 & 46.5 & 53.6 & 54.4 \\
Tannins & 0.67 & 0.40 & 0.67 & 0.70 & 0.87 \\
\hline
\end{tabular}

' hulls defatted with petroleum: " calculated as foltows: 100 - crude protein - crude fat - sugar - crude ash

TABLE 2

Amino acid content $(\mathrm{g} / 16 \mathrm{~g} \mathrm{~N})$ of $\mathrm{RM}$ and its fractions

\begin{tabular}{lrrrr}
\hline Amino acid & RM & Flour & Bran & dHulls' \\
\hline Threonine & 4.73 & 4.55 & 4.85 & 4.57 \\
Glutamic acid & 21.08 & 21.31 & 19.91 & 15.77 \\
Valine & 5.60 & 5.46 & 5.65 & 5.17 \\
lsoleucine & 4.24 & 4.22 & 4.20 & 3.65 \\
Leucine & 7.80 & 7.82 & 7.44 & 6.22 \\
Tyrosine & 2.91 & 2.90 & 3.00 & 2.94 \\
Phenylalanine & 4.26 & 4.27 & 4.20 & 4.15 \\
Histidine & 2.87 & 2.92 & 2.78 & 2.30 \\
Lysine & 5.39 & 5.45 & 5.59 & 5.37 \\
Arginine & 6.06 & 6.06 & 5.79 & 4.21 \\
Cystine & 2.42 & 2.79 & 2.47 & 2.54 \\
Methionine & 2.11 & 2.31 & 2.08 & 2.07 \\
Tryptophan & 1.40 & 1.38 & 1.39 & 1.35 \\
\hline
\end{tabular}

${ }^{\prime}$ huils defatted with petrolcum 
higher and hulls lower than in RM by 1 and $2.2 \mathrm{MJ} \mathrm{AME}_{\mathrm{N}} / \mathrm{kg}(\mathrm{P} \leq 0.01)$, respectively (Table 3). The metabolisable energy value of RM and its fractions was correlated negatively ( $\mathrm{P} \leq 0.01)$ with $\mathrm{CF}, \mathrm{ADF}$ and NDF content. The regression equations were as follows:

$\mathrm{AME}_{\mathrm{N}}(\mathrm{MJ} / \mathrm{kg} \mathrm{DM})=13.11-0.31 \times \% \mathrm{CF} \quad \pm 0.55(\mathrm{r}=-0.90)$

$\mathrm{AME}_{\mathrm{N}}(\mathrm{MJ} / \mathrm{kg} \mathrm{DM})=12.11-0.12 \times \%$ ADF $\pm 0.56(\mathrm{r}=-0.89)$

$A M E_{N}(M J / k g ~ D M)=13.72-0.12 x \%$ NDF $\pm 0.60(r=-0.87)$

Including tannin content into regressions did not improve correlation coefficients.

The regression equations calculated from the results of experiment 2 are presented in Table 4. The partial correlation coefficients between $A M E_{N}$ and crude fibre and crude fat content in M-RMs was -0.60 and 0.61 , respectively. The fat content in $\mathrm{M}-\mathrm{RMs}$ had a significant $(\mathrm{P} \leq 0.05)$, positive, linear effect on their $\mathrm{AME}_{\mathrm{N}}$ value and metabolizability of energy. Crude fibre content had a negative linear effect on both $\mathrm{AME}_{\mathrm{N}}$ and metabolizability of energy of M-RMs. The respective correlation coefficients between $\mathrm{AME}_{\mathrm{N}}$ value and $\mathrm{ADF}$ and $\mathrm{NDF}$ were similar as with crude fibre content (Table 4).

TABLE 3 Apparent organic matter retention (OMR), apparent crude protein (CP), crude fat (Cfat), nitrogenfree extractives (NFE) and neutral-detcrgent fibre (NDF) digestibility (\%) and metabolisabie energy $\left(\mathrm{AME}_{\mathrm{N}}, \mathrm{MJ} / \mathrm{kg} \mathrm{DM}\right)$ of rapeseed meal and its tractions. Experiment 1

\begin{tabular}{|c|c|c|c|c|c|c|}
\hline \multirow{2}{*}{ Product } & \multirow{2}{*}{ OMR } & \multicolumn{4}{|c|}{ Digestibility, \% } & \multirow{2}{*}{$\mathrm{AME}_{\mathrm{N}}$} \\
\hline & & $\mathrm{CP}$ & Cfat & NFE & NDF & \\
\hline Rapeseed meal & $45.0^{\mathrm{AB}}$ & $70.4^{\text {ABals }}$ & $73.0^{\mathrm{A} i \mathrm{a}}$ & $34.1^{B}$ & $37.5^{\mathrm{B}}$ & $9.4^{\mathrm{B}}$ \\
\hline Flour & $47.0^{\mathrm{A}}$ & $80.4^{\mathrm{Ai}}$ & $75.4^{\mathrm{A}: \mathrm{i}}$ & $42.2^{\mathrm{A}}$ & $43.6^{\mathrm{A}}$ & $10.4^{\mathrm{A}}$ \\
\hline Bran & $41.2^{\mathrm{B}}$ & $67.4^{8 \mathrm{~b}}$ & $68.5^{\text {Ait }}$ & $32.5^{\mathrm{B}}$ & $36.1^{\mathrm{B}}$ & $8.5^{B C}$ \\
\hline dHulls & $34.2^{\mathrm{D}}$ & $41.1^{\mathrm{Ca}}$ & $44.2^{\mathrm{Bv}}$ & $19.9^{\mathrm{c}}$ & $17.1^{\mathrm{D}}$ & $7.2^{\mathrm{D}}$ \\
\hline dHulls + bran* & $39.8^{c}$ & $50.4^{\mathrm{Cc}}$ & $54.0^{\mathrm{gh}}$ & $28.5^{\mathrm{B}}$ & $27.5^{\mathrm{C}}$ & $8.1^{\mathrm{CD}}$ \\
\hline SEM & 0.88 & 2.43 & 1.94 & 1.50 & 0.78 & 0.18 \\
\hline
\end{tabular}

* defatted hulls and bran in proportion 1:2; SEM - pooled standard error of the mean

${ }^{\text {a.h }} \mathrm{P} \leq 0.05$; ${ }^{\mathrm{A} . \mathrm{B}} \mathrm{P} \leq 0.01$

TABLE 4

Equations predicting metabolisable energy value $\left(\mathrm{AME}_{\mathrm{N}}\right)$ and metabolizability of energy $\left(\mathrm{AME}_{\mathrm{N}} /\right.$ $\mathrm{EB}$ ) of model rapeseed meals from its fibre (CF, ADF or NDF) and crude fat (C-fat) content (cxpressed as DM \%). Experiment 2

\begin{tabular}{lll}
\hline $\mathrm{AME}_{\mathrm{N}}(\mathrm{MJ} / \mathrm{kg} \mathrm{DM})$ & $=10.78-0.30 \mathrm{CF}+0.20 \mathrm{C}-\mathrm{fat}$ & $\mathrm{S}_{\mathrm{E}} \pm 0.75 ; \mathrm{P} \leq 0.01$ \\
$\mathrm{AME}_{\mathrm{N}}(\mathrm{MJ} / \mathrm{kg} \mathrm{DM})$ & $=9.75-0.12 \mathrm{ADF}+0.21 \mathrm{C}$-fat & $\mathrm{S}_{\mathrm{H}} \pm 0.75 ; \mathrm{P} \leq 0.01$ \\
$\mathrm{AME}_{\mathrm{N}}(\mathrm{MJ} / \mathrm{kg} \mathrm{DM})$ & $=11.55-0.13 \mathrm{NDF}+0.19 \mathrm{C}$ - fat & $\mathrm{S}_{\mathrm{E}} \pm 0.75 ; \mathrm{P} \leq 0.01$ \\
$\mathrm{AME}_{\mathrm{N}} / \mathrm{EB}$ & $=55.00-1.51 \mathrm{CF}+0.52 \mathrm{C}$-fat & $\mathrm{S}_{\mathrm{E}} \pm 3.52 ; \mathrm{P} \leq 0.01$ \\
\hline
\end{tabular}




\section{DISCUSSION}

Rapeseed meal of very small content of glucosinolates was chosen for fractionation, as glucosinolates which are concentrated in dehulled fraction (Seth and Clandinin, 1973) might interfere with the studicd effects of fibre and fat on nutritional value of RM for broiler chickens. In a process of mechanical segregation of RM three fractions of different nutritional value were obtained. About $50 \%$ was separated as flour which contained $16 \%$ more protein and $26 \%$ less crude fibre than RM, about $34 \%$ as bran and $16 \%$ as hulls, both of lower nutritional value than RM. Chemical composition of flour fraction was similar to given by Baudet et al. (1988), similar improvement in protein content and metabolisable energy value was reported by Campbell et al. (1995). The composition of hull fraction was in close agreement with the values reported by Bell and Shires (1982) and Bell (1993) for hull-rich fractions separated from RM. Hullrich fraction separated from the whole seeds contains less residual cotyledons and germs, so its content of protein and fat is usually lower and that of fibre higher than hull-rich fraction separated from RM (Bell, 1993).

Extractable tannin content in the hull fraction was lower than reported by Naczk et al. (1994) but higher than reported by Mitaru et al. (1982) for canola hulls, however according to the last authors these substances did not show inhibiting action against $\alpha$-amylase. Similarly with the results of Seth and Clandinin (1973) fractionation of RM into low-hull and high-hull fractions did not affect in a consistent way the most important essential amino acid content in protein (Table 2).

The apparent digestibility of protein, fat and NFE in evaluated RM was similar to given in European Table (1989) for solvent extracted 00 rapeseed meal, that of protein being lower but that of fat and NFE being slightly higher, by 6,3 and 2 percentagc points, respectively. In the hull fraction apparent digestibility of protcin, fat and NFE was substantially lower than in RM. It scems that protein and fat in the hulls are more tightly interwined with fibre and not prone to the enzymatic digestion in gastrointestinal tract of chickens.

The results of experiment 2 show, that both crude fibre and crude fat content are important for predicting $\mathrm{AME}_{\mathrm{N}}$ value of low glucosinolate rapeseed meals for poultry from its chemical composition. It agrees well with the conclusions of Nwokolo and Bragg (1978). The equation coefficients indicate that $\mathrm{AME}_{\mathrm{N}}$ of $\mathrm{RM}$ is reduced by $0.3 \mathrm{MJ}$ for each per cent of increase of crude fibre and is raised by $0.2 \mathrm{MJ}$ for each per cent of increase in crude fat content. This observation agrees very well with relationship found by Bourdon (1986) between crude fibre and crude fat content of RM and digestible energy in pigs. 


\section{CONCLUSIONS}

The manipulation of fibre and fat content in rapeseed meal is possible; dehulling allows to lower the fibre content, the fat content may increase due to lower extraction rate or omitting the final extraction process. However such manipulations increase the cost of final products and may not be economically justified.

\section{REFERENCES}

Alloui O., Chibowska M., Smulikowska S., 1994. Effects of enzyme supplmentation on the digestion of low glucosinolate rapeseed meal in vitro, and its utilization by broiler chickens. J. Anim. Feed Sci. 3. 119-128

AOAC. 1990. Official Methods of Analysis of the Association of Official Analytical Chemists. 5th Edition. Washington. DC

Baudet J.J.. Burghart P., Evrard J.. 1988. Tourteau à basse teneur en glucosinolates (BTG). Cahier Technique Colza, CETIOM, Paris, pp. 6-31

Bell J. M., 1993. Factors affecting the nutritional value of canola meal: A review. Can. J. Anim. Sci. $73,679-697$

Bell J.M.. Shires A.. 1982. Composition and digestibility by pigs of hull fractions from rapeseed cultivars with yellow or brown seed coats. Can. J. Anim. Sci. 62, 557-565

Bjergegaard Ch. Eggum B.O., Jensen S.K., Sorensen H., 1991. Dietary fibres in oilsced rape: Physiological and antinutritional effects in rats of isolated IDF and SDF added to a standard diet. J. Anim. Physiol. Anim. Nutr. 66, 69-79

Bourdon D.. 1986. Valeur nutritive des noveaux torteaux et graines entieres de colza a basse teneur en glucosinolates pour le porc a l'engrais. Journées Rech. Porcine 8, 13-28

Byczyniska B.. 1971. The isothiocyanates and oxazolidinethiones determination in rapeseeds. Biul. IHAR 5, 57-6I

Campbell G.L., Camphell L.D., Blair R., 1983. Calculation of metabolizable energy for ingredients incorporated at low levels into a reference diet. Poultry Sci. 62, 705-707

Campbell L.D.. Simbaya J., Zhang W., Slominski B.A., Guenter W., 1995. Nutritive value of dehulled canola meal. Proceedings of 9 International Rapeseed Congress ,Rapeseed Today and Tomorrow". Cambridge (UK), Vol. 1, pp. 179-181

European Table of Energy Values for Poultry Fecdstuffs, 1989. WPSA, Spelderholt Centre for Poultry Research and Extension, Beekbergen (The Netherlands)

Hanczakowski P., Fraś B., 1983. The nutritive value of lull-fat seed and commercial meals from lowglucosinolate low-crucic acid varietics of rape (in Polish). Rocz. Nauk. Zoot. 10, 91-99

Kuhla S., Ebmeier Ch.. 1981. Untersuchungen zum Tanningehalt in Ackerbohnen. Arch. Tierernähr. 31, 573-588

de Lange C.F.M., Gabert V.M., Gillis D., Patience J.F., 1998. Digestible energy contents and apparent ileal amino acid digestibilitics in regular or partial mechanically dehulled canola meal samples fed to growing pigs. Can. J. Anim. Sci. 78, 641-648

Marquardt R. R., 1983. A simple spectrophotometric method for the direct determination of uric acid in avian excreta. Poultry Sci. 59, 369-373

Mitaru B.N., Blair R., Bell J. M., Reichert R.D., 1982. Tannin and fiber contents of rapeseed and canola hulls. Can. J. Anim. Sci. 62, 661-663 
Naczk M., Nichols T., Pink D., Sosulski F., 1994. Condensed tannins in canola hulls. J. Agr. Food Chem. 42, 2196-2200

Nutrient Requirement of Poultry. Recommendations and Nutritive Value of Feedstuffs (in Polish), 1996. 3rd revised Edition. The Kielanowski Institute of Animal Physiology and Nutrition (Editor), Jabłonna (Poland)

Nwokolo E., Bragg D.B., 1978. Factors affecting the metabolizable energy content of rapeseed meals. Poultry Sci. 57, 954-958

Pesti G.M., Ware G.O., 1986. Expressing the variability in results of metabolizable energy assays. J. Nutr. 116, 1385-1389

Seth P.C.C., Clandinin D.R., 1973. Metabolizable energy value and composition of rapesced meal and of fractions derived therefrom by air-classification. Brit. Poultry Sci, 14, 499-505

Smulikowska S., Pastuszewska B., Ochtabiriska A., Mieczkowska A., 1998. Composition and nutritional value for chickens and rats of seeds, cake and solvent meal from low glucosinolate yellow-seeded spring rape and dark-seeded winter rape. J. Anim. Feed Sci. 7, 415-428

Van Soest P.J., Wine R.H., 1967. Use of detergents in the analysis of fibrous feeds. IV. Determination of plant cell-wall constituents. J. Assoc. Off. Anal. Chem. 50, 50-55

\section{STRESZCZENIE}

Wplyw zawartości oleju i wlókna w śrucie rzepakowej i jej frakcjach na ich wartość energetyczną dla kurcząt brojlerów

Niskoglukozynolanową śrutç rzcpakową (RM) rozdzielono na sitach o średinicy oczek 150,270 and $450 \mu \mathrm{m}$ na 3 frakcje: mąkę, otręby i łuskę. Frakcje te i olcj rzepakowy zmieszano w różnych proporcjach aby otzymać 25 modelowych śrut rzepakowych o zawartości włókna surowego 8,8; 10,$3 ; 11.8 ; 13.2$; $14,7 \%$ s.m., a tłuszczu surowego 4,$3 ; 6,3 ; 8,2 ; 10.2$ i 12,1\% s.m. (układ dwuczynnikowy).

Strawność składników odżywczych i wartość energii metabolicznej $\left(\mathrm{AME}_{\mathrm{N}}\right.$ ) śruty rzepakowej, jej frakcji oraz śrut modelowych oznaczono w 2 doświadczeniach bilansowych, przeprowadzonych na 154 kurczętach brojlcrach w wicku 4 tygodni. Po usunięciu otrąb i łuski zawartość białka i $\mathrm{AME}_{\mathrm{N}}$ w pozostałej frakcji zwiększyła się odpowicdnio o $16 \mathrm{i} 10 \% \mathrm{w}$ porównaniu ze śrutą rzepakową. Zawartość włókna surowego ujemnie, a tłuszczu surowego dodatnio wpłynęła na wartość $\mathrm{AME}_{\mathrm{N}}$ modelowych śrut rzepakowych $(\mathrm{P} \leq 0,01)$, zgodnie $z$ następującym równaniem:

$\mathrm{AME}_{\wedge}(\mathrm{MJ} / \mathrm{kg} \mathrm{SM})=10,78-0,30(\%$ włókna surowego $)+0,20(\%$ thuszczu surowego $)$. 